\title{
Malignant giant cell tumor of the uterus: a case report
}

\author{
Tumor maligno de células gigantes do útero: um relato de caso
}

Rivadávio Antunes Menacho de Oliveira', Carlos Eduardo Stecca', Tassiara Silva', Mariana Miyasaki

Piovesana', Veruska Peron ${ }^{1}$, Angela Gordan²

\begin{abstract}
This report describes a rare case of malignant extraosseous giant cell tumor (GCT). It refers to a patient with an initial diagnosis of a locally advanced malignant GCT of the uterus, with disease progression to lung and mediastinum seven months after the diagnosis, requiring first line treatment with chemotherapy. Extraosseous presentation of GCT with early distant dissemination is unusual and the role of systemic cytotoxic treatment remains unclear.
\end{abstract}

Keywords: Giant cell tumor; Uterine; Uterus.

\begin{abstract}
RESUMO
O presente relato descreve uma apresentação clínica rara de um tumor de células gigantes (TCG). O caso relatado se refere a uma paciente portadora de um TCG uterino maligno localmente avançado que evoluiu com metástase pulmonar e mediastinal sete meses após o diagnóstico, necessitando de primeira linha de tratamento com quimioterapia. TCG extraósseo, especialmente quando associado a comportamento agressivo e disseminação à distância precoce e altamente infrequente, e o papel do tratamento sistêmico citotóxico permanece incerto.
\end{abstract}

Descritores: Tumor de células gigantes; Uterino; Útero.

\footnotetext{
1. Londrina Cancer Hospital, Clinical Oncology - Londrina - Paraná - Brazil.

2. Londrina Cancer Hospital, Pathologic Anatomy - Londrina - Paraná - Brazil. Financial support: none to declare.

Conflicts of interest: The authors declare no conflict of interest relevant to this manuscript.

Correspondence author: Rivadávio Antunes Menacho de Oliveira.

E-mail: riva-mt@uol.com.br
} 


\section{INTRODUCTION}

GCTs are often considered benign lesions, usually arising from long bones and vertebrae ${ }^{1,2}$. GCT originating from extraosseous sites are generally considered malignant and are very rare, with limited number of previously reported cases.

GCTs of bone and soft tissue are both considered to be locally aggressive and they share similar histological features, including the presence of large osteoclastic giant cells and histiocytoid mononuclear cells ${ }^{2}$. Based on histogenetical features, soft tissue CGT have been linked to malignant fibrous histiocytoma, a very aggressive sarcoma with early distant dissemination ${ }^{3,4}$.

Soft tissue CGT often presents as a painless, slowgrowing mass in superficial location, and have some distinct features seen on imaging that may help excluding differential diagnosis, which is broad ${ }^{5}$. In regards to treatment, surgical excision with clear margins remain the standard of care for localized and locally advanced disease ${ }^{6}$. The natural history of metastatic soft tissue GCT varies and the role of chemotherapy and best regimen are yet to be defined ${ }^{7}$.

Here we describe an unusual case of a GCT of the uterus, presenting with early distant dissemination after definite treatment with radiation and fleeting response to chemotherapy.

\section{CASE REPORT}

A 57-year-old female patient was referred to our service in August 2017 due to severe metrorrhagia. Shortly, she complicated with hemorrhagic shock requiring management in the intensive care unit (ICU). While on ICU, the patient developed septic shock and renal failure, requiring hemodialysis. She was discharged after 7 weeks of admission.

A biopsy had been performed in another service, with pathological diagnosis of high-grade anaplastic neoplasia with immunohistochemistry suggestive of uterine leiomyosarcoma. A pathology review was performed in our service, reporting the diagnosis of GCT.

On a pelvic magnetic resonance imaging from November, 2017, an increased uterus volume was shown an abnormal growth of body and isthmus region with the presence of a large heterogeneous soft tissue density mass with irregular contours. A central irregular hypodense area was observed, without significant enhancement suggesting a tumor necrosis area measuring $10.2 \times 8.2 \times 8.7 \mathrm{~cm}$ and without evidence of extra-uterine lesions (Figure 1). CT scans from superior abdomen and chest were unremarkable.

The case was discussed in a multidisciplinary clinical meeting and the tumor was deemed unresectable due to the urethral and rectum invasion, but amenable to radiation. In December 2017, patient underwent 16 fractions of pelvic radiotherapy (250 cGy) and remained on surveillance.

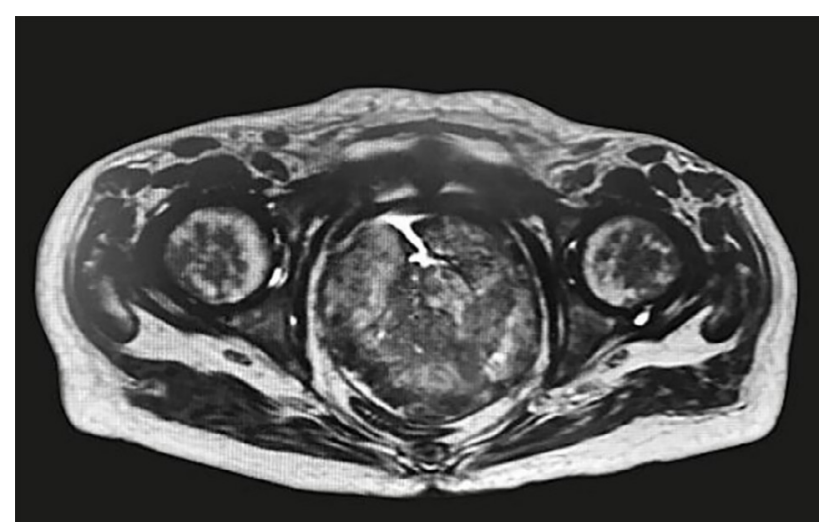

Figure 1. Pelvic magnetic resonance showing a giant cell tumor of the uterus .

Seven months after the diagnosis, restaging scans documented progressive thoracic disease with presence of expansive mediastinal formation measuring $5.2 \times 4.5 \times 4.8 \mathrm{~cm}$, and bilateral pulmonary nodules (Figure 2).

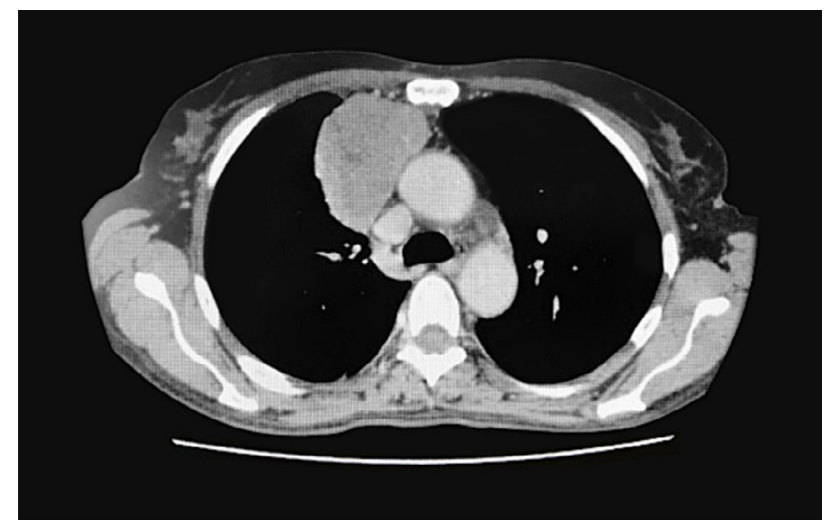

Figure 2. CT scan showing a mediastinal metastasis .

Patient was started on chemotherapy with Cisplatin $\left(60 \mathrm{mg} / \mathrm{m}^{2}\right)$ and Doxorubicin $\left(45 \mathrm{mg} / \mathrm{m}^{2}\right)$ every 21 days, but due to toxicity, schedule was changed to every 28 days. After 3 cycles, CT scans documented a decrease in the dimensions of the pulmonary nodules, mediastinal lesion and uterine formation, now measuring $3.3 \times 2.8 \times 2.9 \mathrm{~cm}$. Due to this partial response by RECIST 1.1 criteria, she continued receiving chemotherapy.

Unfortunately, three months later, in October 2018, there was an uterine progression, with expansive uterine formation measuring $8.6 \times 8.2 \times 12.6 \mathrm{~cm}$ (Figure 3). Treatment with chemotherapy was then suspended after fifth cycle and treatment with Denosumab was judicially requested.

One month later, the patient was admitted to our hospital due to myometritis. At this time, she presented a clinical deterioration and underwent exclusive palliative care, dying two weeks later, accounting 15 months since her diagnosis.

After the patient's death, a consent form was applied to her daughter and the same agreed with sharing her medical information for this publication. 


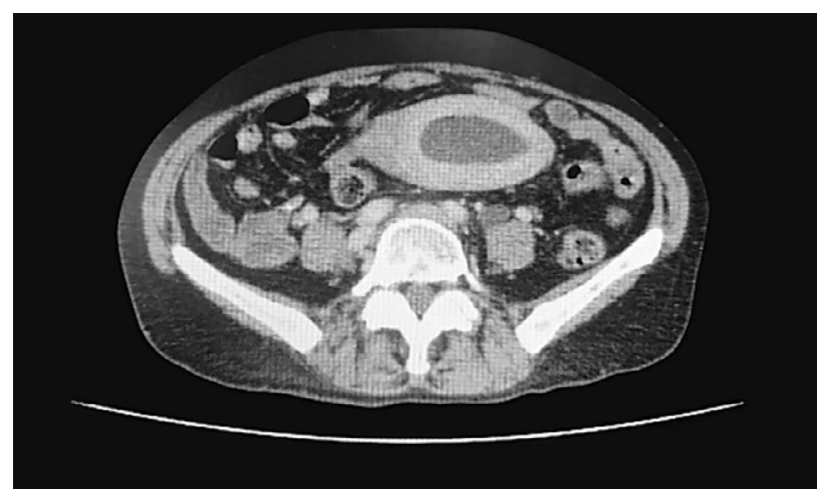

Figure 3. Pelvic magnetic resonance showing an expansive uterine formation (progresion of disease).

\section{PATHOLOGY}

The differential diagnosis of malignant GCT is more challenging than in benign tumors, as giant cells can be found in slightly differentiated carcinomas and sarcomas. These cases require detailed immunohistochemistry. ${ }^{12,13}$

The tumor is considered epithelial if the background cells stain positive to keratin (Cytokeratin AE1/AE3) or epithelial membrane antigen and when they are positive for mesenchymal markers (h-caldesmon, myogenin or DOG1), the tumor is categorized as mesenchymal. ${ }^{8}$ In this present case, stain were negative for all markers, except for those with histiocytic differentiation (CD68), being more consistent with the diagnosis of a malignant giant cell tumor. ${ }^{8,10}$ In summary, the immunohistochemistrycan be heterogeneous, depending on the tumor grade, the malignant potential, and whether neoplasm contains two or more histological components. CD68 usually stains the mononuclear and osteoclastlike cells, CD10 usually shows strong membranous staining for both cell types and cytoplasmic staining in the mononuclear cells, and Cycline D1 is positive in the nuclei of the osteoclast-like giant cells.

In the present case report, the microscopic slide demonstrated the presence of frequent giant cells among atypical mononuclear cells and immunohistochemistry showed positivity for Vimentin and CD68 in the mononuclear component. Despite the positivity for Cycline D1 in the giant cells, it was negative for Cycline AE1/AE3 and CD10 (Figures 4, 5, 6, 7).

\section{DISCUSSION}

GCTs of bone and of soft tissue are similar in multiple aspects including its histological resemblance. Both tumors are characterized by large osteoclastic giant cells and histiocytoid mononuclear cells. Both often have rich vasculature and can show marked osseous metaplasia. Clinically, they are both considered to be locally aggressive and cytogenetically, GCT of bone typically shows clonal and non-clonal telomeric associations, which has also been reported in GCT of soft tissue. There are also some differences found between the two conditions, including the multinodular patter, only seen in soft tissue GCT and

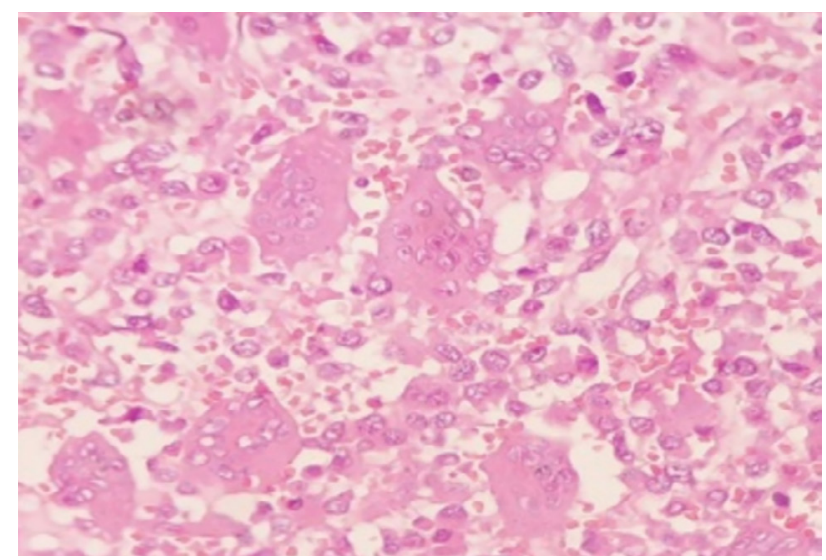

Figure 4. Hematoxylin and eosin (original magnification x400). Presence of frequent giant cells among atypical mononuclear cells.

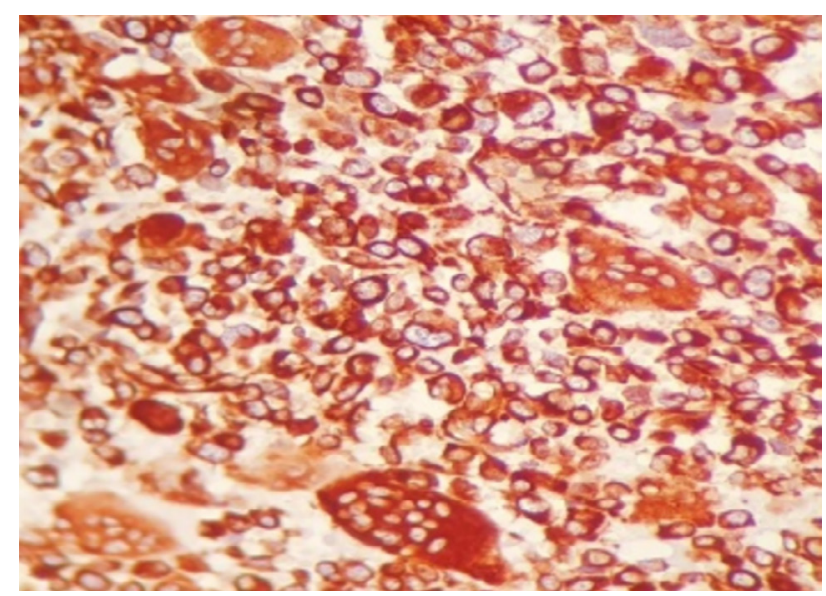

Figure 5. Strongly positive vimentine (x400).

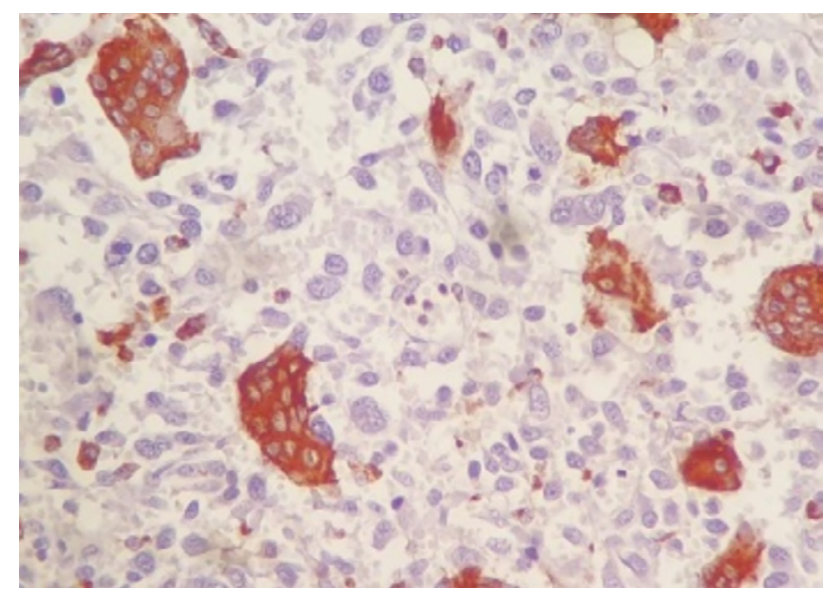

Figure 6. CD 68 positive in multinucleated giant cells (x400) CD68 showing positivity in osteoclast-like giant cells and in mononuclear cells (x400).

the fact that GCT of bone affects mostly young to middle-aged adults, as opposed to a wider range of age described in its soft tissue counterpart. ${ }^{2}$ Based on histogenetical features, a study by Soule and Enriquez ${ }^{4}$ linked the soft tissue CGT to malignant fibrous histiocytoma, and it has now been currently discussed as the giant cell variant of malignant 


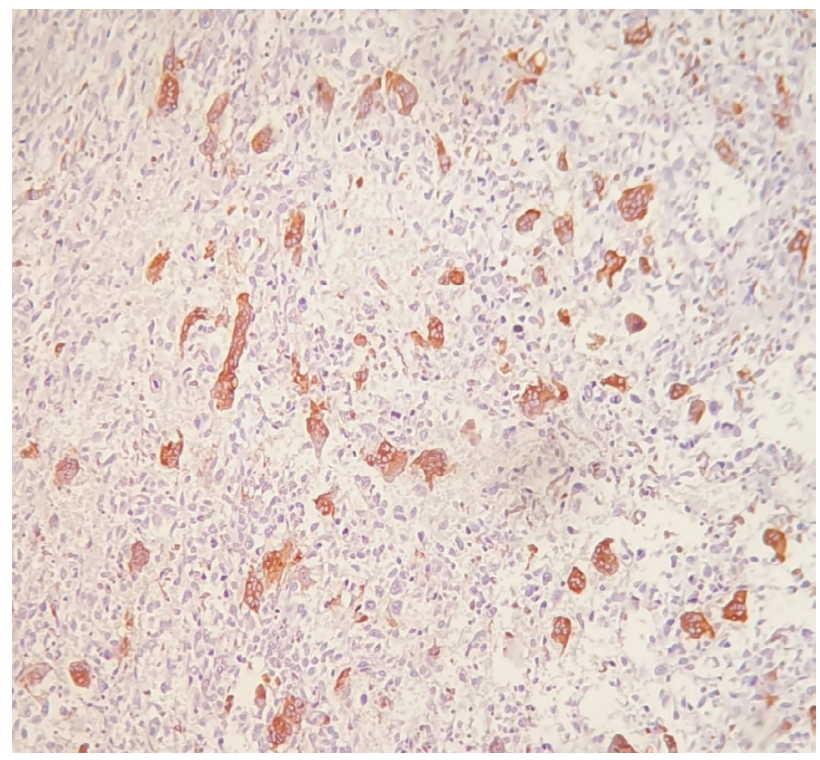

Figure 7. Cicline D1 positive in giant cells, nuclear standard (x400).

fibrous histiocytoma. Those are considered very aggressive sarcomas with high chances of early dissemination ${ }^{3,14}$.

GCTs are benign, lytic, and expansive lesions of bone, usually seen in epiphysis of long bones in young adults. They have the presence of (osteoclastic like giant cells) OLGCs, that are interspersed uniformly between mononuclear stromal cells with histiocytic appearance. Although the origins and histogenesis of GCTs remain unknown, it has been reported that the mononuclear cells of GCT can produce chemoattractant proteins that are involved in recruiting CD68+ macrophage-like cells, which are thought to be the precursors of OLGCs. GCTlike tumors have been reported in a wide variety of extraosseous sites. More commonly, however, OLGCs are a reactive component of a poorly differentiated carcinoma or sarcoma. ${ }^{11}$

GCT of soft tissues are very rare, with limited number of cases reported in the literature. ${ }^{10}$ OLGCrich neoplasms without clearly evident epithelial or mesenchymal differentiation are very rare in the uterus. The number of cases documented worldwide is limited, and include two that were associated with, but topographically distinct from a uterine leiomyosarcoma. ${ }^{3}$ Three patients whose follow up was available died from the disease. Four of the cases were thought to also have smooth muscle differentiation. ${ }^{15,16}$

Many benign and malignant tumors contain osteoclast-like giant cells. The distinction between these tumors and GCT is the spatial relation between giant cells and tumor cells. In a GCT, the giant cells are evenly distributed by the tumor. In other tumors, the giant cells tend to be grouped frequently in areas of hemorrhage. ${ }^{9,11}$ Sometimes, GCTs of soft tissue are indistinguishable clinically and histopathologically from GCTs of bone. GCTs of soft tissues occurred predominantly in the lower extremities of middleaged adults of both sexes. In a previous report, only one patient (6\%) experienced local recurrent disease, developed pulmonary metastasis, and died of tumor. In 96\%, mitotic activity was observed; areas of stromal hemorrhage and foci of hemosiderin deposition were seen in 50\%; necrosis was found in one patient (6\%) and metaplastic bone formation was identified in nine tumors (40\%). ${ }^{3}$

Important differential diagnoses include osteosarcoma, fibrosarcoma, brown malignant fibrous histiocytoma in hyperparathyroidism, giant cells granulomas and metastatic carcinomas ${ }^{14}$. GCT of the uterus should also be included as a differential diagnosis of benign or malignant tumors containing giant OLGCs ${ }^{8,11}$.In the female genital tract, OLGCs have most commonly been reported as a component of uterine leiomyosarcomas, but they have also been described in an endometrial stromal tumor, uterine pleomorphic rhabdomyosarcoma, an endometrial adenosquamous carcinoma, a variety of ovarian tumors, and a sarcomatoid carcinoma of the cervix. ${ }^{17,18}$

Given the rarity of this condition, there are still no consensus regarding the most appropriate treatment, but for localized tumors, when feasible, surgical approach is recommended, followed or not by adjuvant radiation. ${ }^{21,22}$

In the case herein reported, there was progressive disease to the lungs, which is very unusual in this type of tumor. The role of chemotherapy for this condition is yet to be defined. Skubitz, K. M. \& Manivel, J. C reported the case of a 55-year-old patient with GCT and pulmonary metastasis. Two months after the hysterectomy, progressive disease to the lungs was noted on CT imaging. She was treated with pegylated-liposomal Doxorubicin plus Bevacizumab in the first line setting, and with Gemcitabine plus Bevacizumab in the second line. Both treatments failed to demonstrate response, with documented progressive disease in the first restaging scans. Third line treatment was attempted with Ifosfamide, Etoposide and Bevacizumab, after which a partial response was observed after two months, with stabilization at four months. ${ }^{21}$ Angiogenic growth factor expression, including VEGF, has been previously reported in a variety of sarcomas and in GCT of bone, providing a rationale for the potential role of therapy directed against the VEGF signaling pathway, such as Bevacizumab. ${ }^{19}$

Hulya Ayik Aydin et al option was the administration of adjuvant Carboplatin and Paclitaxel chemotherapy after the decision of the multidisciplinary council. Primary tumor surgery was applied here. ${ }^{17}$

Another rare histological variation previously described is GCT rich in squamous cell carcinoma with only 4 cases reported in the literature. This tumor subtype contains numerous osteoclastic giant cells with abundant eosinophilic cytoplasm devoid of nuclear atypia, hyperchromatism or mitotic activity. 
On immunohistochemistry, CK and P63 were strongly positive in the squamous component and negative in osteoclastic giant cells. ${ }^{12,23}$

David Thomas et al investigated the potential therapeutic effect of Denosumab, a fully human monoclonal antibody against RANKL, on tumor-cell survival and growth in patients with GCT. Thirty-seven patients with recurrent or unresectable GCT were enrolled and received subcutaneous Denosumab 120 mg monthly (every 28 days), with loading doses on days 8 and 15 of month 1. The primary endpoint was overall response rate. Eighty-six percent of evaluable patients had a tumor response, but despite promising activity, further investigation of Denosumab as a therapy for GCT is still warranted. ${ }^{12,15}$ Studies also suggest that bisphosphonates may induce apoptosis in both osteoclast-like giant cells and stromal tumor cells in vivo and in vitro in GCT, possibly by interfering with an autocrine and/or paracrine loop in the tumor between stromal tumor cells and osteoclast-like giant cells. ${ }^{20}$

In summary, we have reported a case of uterine GCT resembling the GCT of bone. Our report focuses and emphasizes on the importance of a thorough clinical evaluation and review by expert pathologist. GCT of soft tissue might be genetically different from its osseous counterpart, and these two tumor types might therefore be better regarded as two distinct entities. More studies are warranted to shed light on the pathogenesis of GCT of soft tissue..$^{8,14}$ The differential diagnosis is challenging, as giant cells can be found in carcinomas and poorly differentiated sarcomas. For this reason, a qualified team is imperative in order to obtain better patient outcomes.

\section{REFERENCES}

1. Catalan J., et al. Tumor de células gigantes ósseo: aspectos clínicos e radiográficos de 115 casos. Radiol Bras vol.39 no.2 São Paulo Mar./ Apr. 2006. http://dx.doi.org/10.1590/S010039842006000200009.

2. Lee, JC., Liang, CW. \& Fletcher, C. Giant cell tumor of soft tissue is genetically distinct from its bone counterpart. Mod Pathol 30, 728-733 (2017). https://doi.org/10.1038/modpathol.2016.236

3. Oliveira AM, Dei Tos AP, Fletcher CD, Nascimento AG. Primary giant cell tumor of soft tissues: a study of 22 cases. Am J Surg Pathol. 2000 Feb;24(2):248-56. doi: 10.1097/00000478200002000-00011. PMID: 10680893.

4. Soule EH, Enriquez P. Atypical fibrous histiocytoma, malignant fibrous histiocytoma, malignant histiocytoma, and epithelioid sarcoma. A comparative study of 65 tumors. Cancer 1972;30:128-43

5. Guccion JG, Enzinger FM. Malignant giant cell tumor of soft parts. An analysis of 32 cases. Cancer. 1972;29(6):1518-1529. doi:10.1002/1097-0142(197206)29:6<1518::aidcncr2820290616>3.0.co;2-\#
6. Mavrogenis AF, Tsukamoto $S$, Antoniadou T, Righi A, Errani C. Giant Cell Tumor of Soft Tissue: A Rare Entity. Orthopedics. 2019;42(4):e364-e369. doi:10.3928/01477447-20190624-04

7. Pilon VA, Parikh N, Maccera J (1986). Malignant osteoclast-like giant cell tumor associated with uterine leiomyosarcoma.

8. GynecolOncol. 1986; 23:381-386.8.8 Bennett, J.; Sanada, S.; Selig, M.; Hariri, L.; Nielsen, G.; Oliva, E. (2015). Giant cell tumor of theuterus: a report of 3 cases with a spectrum of morphologic features. Int J GynecolPathol2015 Jul;34(4):34050. doi10.1097/PGP.0000000000000164.

9. Darby AJ, Papadaki L, Beilby JO (1975). An unusual leiomyosarcoma of the uterus containing osteoclastlike giant cells. Cancer. 1975; 36:495-504.

10. Watanabe K, Hiraki H, Ohishi M, et al (1996). Uterine leiomyosarcoma with osteoclast-like giant cells: histopathological and cytological observations. Pathol Int. 1996;46:656-60. 10.

11. Fadare O, McCalip B, Mariappan MR, Hileeto D, Parkash V (2005). An endometrial stromal tumor with osteoclast-like giant cells: expanding the morphological spectrum. Ann Diag Pathol. 2005; 9:160-165.

12. Thomas DM, Skubitz KM. Giant cell tumor of bone. CurrOpinOncol. 2009; 21:338-344.

13. Niti Manglik, JanuszSawicki, Andre Saad, Oluwole Fadare, Robert Soslow, and Sharon X. Liang (2012). Giant Cell Tumor of Uterus Resembling Osseous Giant Cell Tumor: Case Report and Review of Literature. International Journal of Surgical Pathology 20(6) 618-622. DOI: $10.1177 / 1066896912436554$

14. O'Connell JX, Wehrli BM, Nielsen GP, Rosenberg AE. Giant cell tumors of soft tissue: a Clinicopathologic study of 18 benign and malignant tumors. Am J Surg Pathol. 2000 Mar;24(3):386-95. doi: 10.1097/00000478200003000-00007. PMID: 10716152.

15. Magni E, Lauritzen AF, Wilken-Jensen C, Horn T: Malignant giant cell tumour of the uterus. APMIS Suppl 1991, 23:113-118.

16. Sieinski W: Malignant giant cell tumor associated with leiomyosarcoma of the uterus. Cancer 1990, 65:1838-1842.

17. Hülya Ayık Aydın, Hasan Aykut Tuncer , Gülgün Erdoğan, Tayup Şimşek: Uterine giant cell carcinoma: a case report and review of the literature. Turk J Obstet Gynecol. 2019 Mar;16(1):76-79

18. Aru A, Norup P, Bjerregaard B, Andreasson $B$, Horn T. Osteoclast-like giant cells in leiomyomatous tumors of the uterus. A case report and review of the literature. Acta Obstet Gynecol Scand. 2001;80:371-374. 
19. Zheng $M H, X u$ J, Robbins $P$, Pavlos $N$, Wysocki S, Kumta SM, Wood DJ, Papadimitriou JM: Gene expression of vascular endothelial growth factor in giant cell tumors of bone. Hum Pathol 2000, 31:804-812.

20. Chang SS, Suratwala SJ, Jung KM, Doppelt JD, Zhang $\mathrm{HZ}$, Blaine TA, Kim TW, Winchester RJ, Lee FY: Bisphosphonates may reduce recurrence in giant cell tumor by inducing apoptosis. Clin Orthop Relat Res 2004:103-109.

21. Skubitz, K. M., \&Manivel, J. C. (2007). Giant cell tumor of the uterus: case report and response to chemotherapy. BMC cancer, 7, 46.doi:10.1186/14712407-7-46
22. Pilon VA, Parikh N, Maccera J (1986). Malignant osteoclast-like giant cell tumor associated with uterine leiomyosarcoma. GynecolOncol. 1986; 23:381-386

23. Alemán-Meza L, Gómez-Macías GS, BarbozaQuintana O, Garza-Guajardo R, Loya-Solis A. Osteoclastic giant cell rich squamous cell carcinoma of the uterine cervix: a case report and review of the literature. Case Rep Pathol. 2014; 2014:415328. 